\title{
A review of the development of high temperature proton exchange membrane fuel cells
}

\author{
Suthida Authayanun a , Karittha Im-orb b, Amornchai Arpornwichanop b,* \\ a Department of Chemical Engineering, Faculty of Engineering, Srinakharinwirot University, Nakhon Nayok 26120, Thailand \\ ${ }^{\mathrm{b}}$ Computational Process Engineering Research Unit, Department of Chemical Engineering, Faculty of Engineering, Chulalongkorn University, Bangkok \\ 10330, Thailand
}

\section{A R T I C L E I N F O}

Article history:

Received 17 October 2014

Accepted 13 December 2014

Published 20 April 2015

\section{Keywords:}

High temperature proton exchange

membrane fuel cell

Electrochemistry

Modeling

Fuel options

System design

\begin{abstract}
A B S T R A C T
Due to the need for clean energy, the development of an efficient fuel cell technology for electricity generation has received considerable attention. Much of the current research efforts have investigated the materials for and process development of fuel cells, including the optimization and simplification of the fuel cell components, and the modeling of the fuel cell systems to reduce their cost and improve their performance, durability and reliability to enable them to compete with the conventional combustion engine. A high temperature proton exchange membrane fuel cell (HT-PEMFC) is an interesting alternative to conventional PEMFCs as it is able to mitigate $\mathrm{CO}$ poisoning and water management problems. Although the HT-PEMFC has many attractive features, it also possesses many limitations and presents several challenges to its widespread commercialization. In this review, the trends of HT-PEMFC research and development with respect to electrochemistry, membrane, modeling, fuel options, and system design were presented.
\end{abstract}

(C) 2015, Dalian Institute of Chemical Physics, Chinese Academy of Sciences. Published by Elsevier B.V. All rights reserved.

\section{Introduction}

A proton exchange membrane fuel cell (PEMFC) offers the highest energy density among the many types of fuel cells. Due to its low temperature operation between 60 to $80{ }^{\circ} \mathrm{C}$, PEMFCs can start quickly and provide good responses to changes in power demand [1,2]. Other advantages of the PEMFCs include their low weight and volume and high power density. These advantages of the PEMFCs make them promising candidates for applications in transportation and in portable and small stationary applications. However, there are several difficulties in the operation of a PEMFC that still need to be resolved. The intrinsic problems of PEMFCs are water management and CO poisoning. Due to the proton conduction mechanism in the membrane electrolyte in PEMFCs, the fuel stream must be hu- midified to avoid the loss of PEMFC performance by membrane dehydration. The liquid water generated at the cathode catalyst layer from the electrochemical reaction and the proton conduction mechanism (electro-osmotic drag) causes a water flooding problem. In addition, trace CO in the hydrogen-rich gas can strongly adsorb on the surface of Pt and block the hydrogen oxidation reaction (HOR) sites. This will dramatically reduce the activity of Pt or Pt alloy in the anode, which results in the deterioration of PEMFC performance.

Recently, a high temperature PEMFC (HT-PEMFC) operated between 100 and $200{ }^{\circ} \mathrm{C}$ was developed. The operation of the PEMFC at high temperature reduced the $\mathrm{CO}$ poisoning problem and gave it a high tolerance for CO. Therefore, the high temperature operation of PEMFCs can improve the PEMFC performance when it is operated with a reformate gas. Another ad-

\footnotetext{
*Corresponding author. Tel: +66-2-218-6878; Fax: +66-2-218-6877; Email: Amornchai.A@chula.ac.th This work was supported by the Thailand Research Fund and the Ratchadaphiseksomphot Endowment Fund, Chulalongkorn University. DOI: 10.1016/S1872-2067(14)60272-2 | http://www.sciencedirect.com/science/journal/18722067 | Chin. J. Catal., Vol. 36, No. 4, April 2015
} 
vantage of the HT-PEMFC is that the electrochemical reaction rates at the anode and cathode are increased and water management within the PEMFC is simplified. In addition, the released heat from the HT-PEMFC can be applied for hydrogen production and a co-generation system.

This review focuses on the development of the HT-PEMFCs reported in the literature. The basic operation and principle of the HT-PEMFC are explained. The development of proton exchange membranes for high temperature operation is summarized. Since several types of fuels, including hydrogen, reformate gas and methanol, can be used in the operation of HT-PEMFCs, the effects of the fuel on the performance of the HT-PEMFC are discussed. A description of the electrochemistry involved in the oxidation of hydrogen and the reduction of oxygen is given in terms of the limitations and the approaches to overcome the limitations of the reactions. The various models of the HT-PEMFCs in the literature are reviewed to understand the design and control of complex PEMFCs. The trends in the integration of the HT-PEMFC process with a fuel processor and the heat and power systems are considered. The heat integration between the hydrogen production process and the other heat requirement systems in the HT-PEMFCs are also discussed.

\section{Principle and theory of HT-PEMFCs}

The HT-PEMFC is a promising PEMFC technology that was developed to solve the main problems of a conventional, low temperature PEMFC (LT-PEMFC), namely, CO poisoning of the Pt catalyst and water management in both the gas diffusion layer and the membrane. Compared to the LT-PEMFC, which is operated between 60 to $80{ }^{\circ} \mathrm{C}$, the HT-PEMFC provides a higher power efficiency and a wider range of thermal energy usage. The HT-PEMFC is operated at high temperatures between 100 to $200{ }^{\circ} \mathrm{C}$. Under the high temperature operation, the amount of CO that adsorbs on the Pt catalyst in the HT-PEMFC is reduced, which results in a high $\mathrm{CO}$ tolerance. Therefore, the operation of the PEMFC at high temperature can mitigate the CO poisoning problem. In addition, the higher operating temperature of the PEMFC also increases the electrochemical reaction rates at the anode and cathode and simplifies water management in the PEMFC. When the PEMFC is operated at temperatures above $100{ }^{\circ} \mathrm{C}$, water is only present in the vapor phase and thus the flooding problem is solved and the transport of water is easily balanced. However, the operation of the PEMFC at high temperature leads to the dehydration of the membrane and the loss of the membrane's ionic conductivity. The development of novel membranes that can be operated at temperatures higher than $100{ }^{\circ} \mathrm{C}$ and that exhibits high conductivity under a low humidity is a critical issue.

Basically, the HT-PEMFC structure is similar to a conventional PEMFC. Both consists of a polymeric proton-conductive membrane sandwiched between an anode and a cathode backing layer (or gas diffusion layer, GDL), as shown in Fig. 1, but they differ in the type of membrane utilized. The electrodes must be porous so that the gaseous reactants can diffuse to the interface between the electrodes and the membrane to the

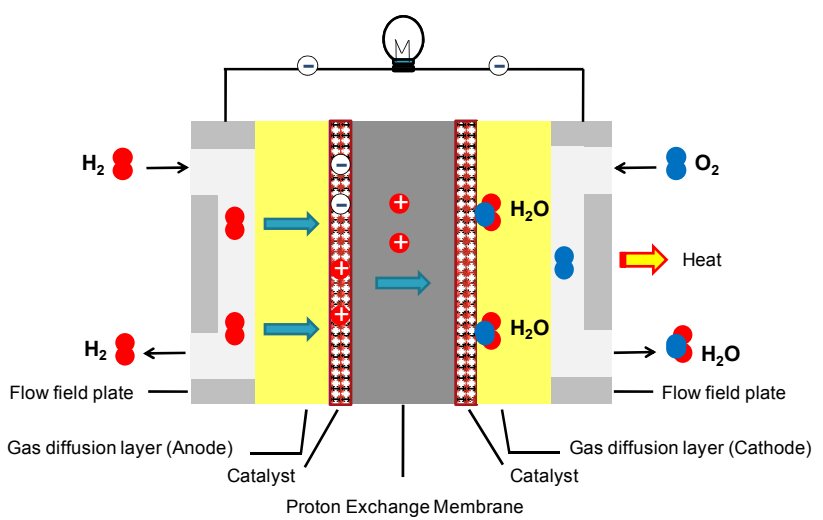

Fig. 1. Schematic of an HT- PEMFC.

surface of the catalyst layer where the electrochemical reactions take place. During the operation of the HT-PEMFC, hydrogen is fed into the anode side without humidification where it is dissociated into its primary constituents, protons and electrons, (Eq. (1)), at the catalyst (Pt) layer. The protons subsequently migrate through the membrane from the anode to the cathode side, while the electrons go through the electrically conductive electrodes to the outside circuit and return to the cathode. At the cathode, the electrons react with the protons from the anode side and with the oxygen (Eq. (2)). Water is produced in this electrochemical reaction and is removed from the cell by a flow of excess oxygen.

Anode: $2 \mathrm{H}_{2} \rightarrow 4 \mathrm{H}^{+}+4 \mathrm{e}^{-}$

Cathode: $\mathrm{O}_{2}+4 \mathrm{H}^{+}+4 \mathrm{e}^{-} \rightarrow 2 \mathrm{H}_{2} \mathrm{O}$

Due to the high CO tolerance of the HT-PEMFC compared to the conventional PEMFC, a reformate gas can be used as fuel without complex CO removal processes. This makes the design of the fuel processor for the HT-PEMFC simpler. The typical HT-PEMFC system is presented in Fig. 2(a). It does not have any of the variety of $\mathrm{CO}$ removal approaches, such as the preferential oxidation process, pressure swing adsorption, CO methanation process or process involving a membrane separation and humidifier, that is required for the conventional PEMFC system, which are shown in Fig. 2(b).

\section{Proton exchange membrane for HT-PEMFC}

Apart from the operating temperature, the main difference between the conventional PEMFC and HT-PEMFC is the type of proton exchange membrane. The well-known membrane material for the PEMFC is NafionTM, which is made of a perfluorocarbon-sulfonic acid ionomer. The fuel needs to be saturated with steam before it is fed to cell from the anode side to prevent the drying out of the Nafion membrane. This is because the proton transport mechanism (vehicle or hopping mechanism) across this membrane uses water as a proton carrier. Although the operation of the PEMFC at an elevated temperature can eliminate the flooding problem, it leads to the dehydration of the membrane and loss of membrane ionic conductivity. Therefore, many researchers pay attention to developing a new membrane that can be operated at temperatures above $100{ }^{\circ} \mathrm{C}$ and has a high conductivity at low humidity. In addition, 


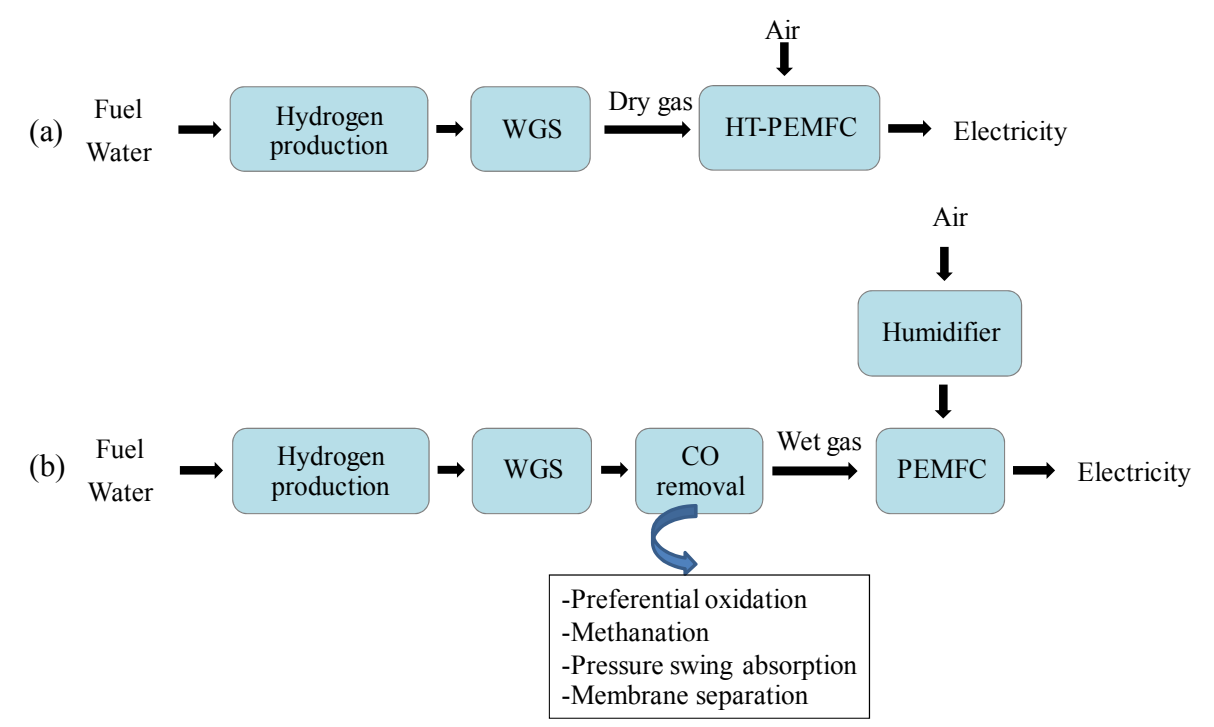

Fig. 2. PEMFC system integrated with fuel processing. (a) HT-PEMFC system; (b) Conventional PEMFC system.

the developed membrane should have a low material cost and high durability [3]. There are several developed membranes for the HT-PEMFC, such as inorganic-organic composite membranes, sulfonated hydrocarbon polymers and acid-base polymer membranes. The composite membrane is developed by combining filler materials, such as $\mathrm{SiO}_{2}, \mathrm{ZrO}_{2}, \mathrm{Al}_{2} \mathrm{O}$, clays (montmorillonite), zeolites, $\mathrm{HCl}, \mathrm{H}_{3} \mathrm{PO}_{3}$, heteropoly acids and zirconium phosphates ( $\mathrm{ZrP}$ ), with the membrane to maintain water uptake at high temperature and a lower humidity. With the use of hydrophilic groups, the inorganic filler material can improve water adsorption and reduce water crossover of the membrane and also increase proton conductivity. A solid material which can be immobilized in the membrane has a better performance than a liquid hydrophilic additive that has a leaching problem. Due to their high water uptake over a broad temperature range and high mechanical and thermal stability, sulfonated hydrocarbon polymers have also been developed for the PEMFC operated at high temperature. Sulfonated polyetherketones, such as SPEK, SPEEK, SPEEKK, SPEKEKK have been extensively investigated because of the low cost and high stability of these polymers.

However, the limitation of these membranes is that they have to be hydrated to achieve a high proton conductivity. Therefore, acid-base polymer membranes have been developed. The use of a non-aqueous solvent as a proton carrier instead of water and a solid state material as the medium of proton conduction has received much attention. One of the more interesting acid-base polymer membrane is polybenzimidazole (PBI) doped with phosphoric acid. Actually, the proton conductivity of PBI is quite low and thus it is doped with dopants, such as sulfuric acid, nitric acid, hydrocholic acid and phosphoric acid. Phosphoric acid has many advantages in terms of a higher stability compared to the other acids. The proton conductivity mechanism of PBI doped with phosphoric acid is called the 'Grotthus mechanism' which is shown in Eqs. (3)-(5). The rate of phosphoric acid loss during cell operation should be minimized and the phosphoric acid doping level should be optimized by a trade-off between proton conductivity and mechanical stability. Extensive reviews on the proton exchange membrane have been published by many researchers [3-7].

$$
\begin{aligned}
& \text { Anode: } \mathrm{H}_{2} \mathrm{PO}_{4}^{-}+\mathrm{H}^{+} \Leftrightarrow \mathrm{H}_{3} \mathrm{PO}_{4} \\
& \text { Membrane: } \mathrm{H}_{3} \mathrm{PO}_{4}+\mathrm{PBI} \Leftrightarrow \mathrm{H}_{2} \mathrm{PO}_{4}^{-}+\mathrm{PBI} \cdot \mathrm{H}^{+} \\
& \text {Cathode: } \mathrm{PBI} \cdot \mathrm{H}^{+} \Leftrightarrow \mathrm{PBI}+\mathrm{H}^{+}
\end{aligned}
$$

\section{Electrochemistry of HT-PEMFCs}

The catalyst used to catalyze the electrochemical reaction at the anode and cathode of both the conventional and high temperature PEMFCs is platinum (Pt). The electrochemical reaction in the catalyst layer takes place at the three phase boundary of the ionomer, solid and void phases. However, the reaction zone is not limited to a single three phase boundary and the catalyst surface is covered by a thin film electrolyte. The reactants need to be transported through the thin film electrolyte to the active area of the catalyst. The reaction rates depend on the kinetics of electron transfer, resistance in the transport of the reactants, and resistance in the transport of protons in the catalyst layer.

\subsection{Hydrogen oxidation}

The oxidation of hydrogen at the anode catalyst of the HT-PEMFC is known to take place in two steps: dissociative adsorption and electrochemical oxidation, as shown in Eqs. (6) and (7). The dissociative adsorption of a hydrogen molecule requires two free platinum catalyst reaction sites (M). The electrochemical oxidation of the dissociatively adsorbed hydrogen produces two free platinum sites, two protons, and two electrons. For hydrogen oxidation, the dissociative adsorption and electrochemical oxidation occur quickly due to the large value of the exchange current density. The anode overpotential is less than $100 \mathrm{mV}$ under the operational conditions [8]. 


$$
\begin{gathered}
\mathrm{H}_{2}+2 \mathrm{M} \Leftrightarrow 2(\mathrm{M}-\mathrm{H}) \\
2(\mathrm{M}-\mathrm{H}) \Leftrightarrow 2 \mathrm{H}^{+}+2 \mathrm{e}^{-}+2 \mathrm{M}
\end{gathered}
$$

For a reformate gas obtained from a fuel processing process, the remaining trace $\mathrm{CO}$ in the reformate gas can strongly adsorb onto the surface of the Pt and compete with hydrogen for the adsorption sites [9]. The bonding of adsorbed CO on the Pt active site is of two types: linearly bonded and bridge-bonded, as shown in Eqs. (8) and (9). The linearly adsorbed carbon monoxide species involves one adsorption site per CO molecule, while the bridge-bonded $\mathrm{CO}$ species requires two platinum surface sites.

$$
\begin{gathered}
\mathrm{CO}+\mathrm{M} \Leftrightarrow \mathrm{M}-\mathrm{CO} \\
\mathrm{CO}+2 \mathrm{M} \Leftrightarrow 2 \mathrm{M}-\mathrm{CO}
\end{gathered}
$$

The performance of the PEMFC fed with a reformate gas is typically dependent on the amount of CO in the fuel feed stream, temperature, and current density [10]. Under operation at high temperature, the amount of $\mathrm{CO}$ that adsorbs onto the $\mathrm{Pt}$ catalyst in the HT-PEMFC is reduced, which results in a high CO tolerance. This increased tolerance is related to the thermodynamics of the adsorption of $\mathrm{CO}$ and $\mathrm{H}_{2}$ on the Pt electrocatalyst. Since hydrogen adsorption is less exothermic than CO adsorption, an increase in temperature leads to a beneficial shift towards lower CO coverage and higher $\mathrm{H}$ coverage. Therefore, the operation of the PEMFC at high temperature can mitigate the CO poisoning problem. Due to high CO tolerance of the HT-PEMFC and lower reaction rate at the cathode, catalyst development for the cathode reduction reaction has received higher considerable more attention than the development of the anode catalyst [11]. Studies on the oxidation of hydrogen at the anode have been focused on the development of CO poisoning models.

On the other hand, the HT-PEMFC can be operated with a dry fuel gas due to the mechanism of proton conduction in the PBI membrane, which differs from that in the Nafion membrane of the conventional PEMFC. Some studies have recently focused on the HT-PEMFC fueled by humidified hydrogen and have proposed that $\mathrm{CO}$ electrooxidation can occur under this condition [11-14]. Linares et al. [12] concluded that the presence of water in the anode feed reduced $\mathrm{CO}$ poisoning by a lower CO coverage. Water can help to clean the anode catalyst adsorbing $\mathrm{CO}$ molecules by an electrochemical oxidation of $\mathrm{CO}$ on the platinum sites by a bifunctional mechanism, where the dissociation of water provides $\mathrm{OH}$ groups to oxidize $\mathrm{CO}$ adsorbed on Pt sites to $\mathrm{CO}_{2}$. This is shown in Eqs. (10)-(12) $[15,16]$.

$$
\begin{aligned}
\mathrm{M}+\mathrm{H}_{2} \mathrm{O} & \Leftrightarrow \mathrm{M}-\mathrm{OH}+\mathrm{H}^{+}+\mathrm{e}^{-} \\
\mathrm{M}-\mathrm{CO}+\mathrm{M}-\mathrm{OH} & \Leftrightarrow 2 \mathrm{M}+\mathrm{CO}_{2}+\mathrm{H}^{+}+\mathrm{e}^{-} \\
2 \mathrm{M}-\mathrm{CO}+\mathrm{M}-\mathrm{OH} & \Leftrightarrow 3 \mathrm{M}+\mathrm{CO}_{2}+\mathrm{H}^{+}+\mathrm{e}^{-}
\end{aligned}
$$

\subsection{Oxygen reduction}

The slow oxygen reduction reaction is a limiting step in low temperature fuel cells, such as the PEMFC, and this requires the use of a noble metal catalyst, such as Pt or Pt-alloy, to provide the highest catalytic activity for the oxygen reduction reaction
[17-20]. The reaction rate of the oxygen reduction reaction is several orders of magnitude lower than the reaction rate of the oxidation of the hydrogen. Due to the sluggish oxygen reduction reaction kinetics, the cathode voltage loss is considered the major voltage loss of PEMFCs. This loss requires the use of a relatively high loading of platinum, especially for the cathode side. A platinum loading of $0.4 \mathrm{mg} / \mathrm{cm}^{2}$ is required to overcome the high voltage loss at the cathode [21]. Therefore, many researchers have looked at catalyst development, including the reduction of the noble metal loading, as well as to study alternative catalysts and their reaction kinetics [17,22]. During operation at high temperature, the reaction kinetics of the oxidation of hydrogen and the reduction of oxygen will be increased [23]. However, the cell performance of the HT-PEMFCs is only approximately half that of the conventional PEMFCs, and higher $\mathrm{Pt}$ loadings are required for the HT-PEMFCs compared to the conventional PEMFCs [24-30]. The slower oxygen reduction kinetics at the cathode of the HT-PEMFCs even at the higher operating temperature is due to several factors, such as low oxygen permeability and strong phosphate adsorption (phosphoric acid is required for the operation of the HT-PEMFCs) [31]. Many studies have concentrated on finding new catalysts with an oxygen reduction reaction activity similar to Pt [24]. The combination of platinum with other metals such as $\mathrm{Pd}, \mathrm{Ru}$, $\mathrm{V}, \mathrm{Cr}, \mathrm{Co}, \mathrm{Ni}$, and $\mathrm{Cu}$ can increase the activity towards the oxygen reduction reaction and is a feasible approach for the PEMFCs [26-28]. The use of a $\mathrm{Pt}$ alloy catalyst can reduce the $\mathrm{Pt}$ loading at the cathode and thus lower costs [25].

The $\mathrm{H}_{3} \mathrm{PO}_{4}$ concentration in the PBI membrane plays a critical role in the HT-PEMFCs in terms of the membrane conductivity and activity of the $\mathrm{Pt} / \mathrm{C}$ catalyst [29]. The cell performance of the HT-PEMFCs is limited by the oxygen reduction reaction and the transport limitation of the protons and reactants in the cathode, especially in the presence of phosphoric acid [30]. Strong phosphoric acid adsorption on the Pt surface results in the blocking of the surface of the Pt for molecular oxygen access, and thus large quantities of the platinum catalyst must be used to facilitate good performance [32,33]. To enhance platinum utilization, several methods have been studied to reduce phosphate adsorption: surface modification of the platinum with cyanide adsorbates, electronic structure modification with $\mathrm{Pt}$ alloys, and core-shell structure modification $\left(\mathrm{Au}_{\text {core }}-\mathrm{Pt}_{\text {shell }} / \mathrm{C}\right)[30,34,35]$. Non-platinum catalysts that are less affected by phosphoric acid have also been investigated to produce cheaper and more efficient fuel cells [36].

\section{Modeling of HT-PEMFCs}

A good understanding of the PEMFC is required for the optimization of its performance and efficiency. Modeling and simulation have become important tools to understand and design the complex and multidisciplinary PEMFC systems where the electrochemical and transport processes are tightly coupled. Compared to the Nafion-based LT-PEMFCs, only a few publications have developed models for the PBI-based HT-PEMFCs.

\subsection{One dimensional models}


Cheddie and Munroe [37] presented a one dimensional mathematical model to predict the polarization performance of an HT-PEMFC using a PBI membrane. The interest was on the membrane electrode assembly (MEA). Mass and energy transport in the gas diffusion layer and in the electrochemical model were analyzed. The largest loss in the PBI fuel cell was from the activation overpotential and the second largest loss was from the ohmic overpotential. This indicated that the conductivity of the membrane and the membrane-catalyst interface should be improved. It should be noted that the membrane conductivity was kept constant in this research.

A steady state, one dimensional model of an HT-PEMFC membrane electrode assembly with a phosphoric acid-doped PBI membrane was developed by Scott et al. [38]. However, they assumed that the cell was operated under isothermal conditions. The Stefan-Maxwell equation and Darcy's Law were used to model the mass transport processes. The effects of the cell temperature, pressure and gas compositions on the voltage and power density were studied. They claimed that this model yielded good agreement with the experimental data and can be used to optimize the electrode structure and electrocatalyst composition. However, the model failed to show a limiting current under operation in air. A one dimensional model of a high temperature polymer electrolyte membrane fuel cell with inclusion of the CO poisoning effect and mass transport through a thin film electrolyte was described by Mamlouk et al. [39].

A one dimensional model for the HT-PEMFC with a phosphoric acid-doped PBI membrane was also developed by Kim et al. [40] to study its degradation. They built a hybrid model that combined the model from reference [37] and developed empirical models to explain the degradation behavior. They proposed that the doping level has a significant effect on the ohmic loss in the membrane and both catalyst layers. The HT-PEMFC has a shorter lifetime with a lower doping level. Kim et al. [41] studied the effect of the cell temperature on the performance and degradation. They concluded that the operating condition at high temperature negatively affected cell performance under long term operation. The optimal operating temperature for a desired lifetime and cell performance can be examined with the model. However, the model can predict the performance and lifetime only in a narrower range than the general target lifetime of current commercial stationary fuel cell systems due to the limit of durability data at different temperatures.

\subsection{Two dimensional models}

Sousa et al. [42] studied a two dimensional isothermal model for an intermediate temperature HT-PEMFC in which a PBI doped phosphoric acid membrane was used as electrolyte. The membrane-electrode-assembly and gas flow channel model was considered. The mass transport limitation in the catalyst layer was taken into account. The catalyst was treated as an agglomerate layer of the solid electrode and the electrolyte. They concluded that the agglomerate catalyst approach can improve the accuracy of the model particularly at high current density and under operation with an air feed. They also pro- posed a dynamic two dimensional non-isothermal model to simulate the transient response of an intermediate temperature fuel cell using a $\mathrm{H}_{3} \mathrm{PO}_{4} / \mathrm{PBI}$ membrane. The influence of the electrode double layer was considered [43].

A pseudo-two dimensional, isothermal model for the HT-PEMFC was developed by Shamardina et al. [44]. The one dimensional electrode model was integrated with the one dimensional flow channel model. The crossover of the reactant gases through the membrane was taken into account. Shamardina et al. [45] developed an isothermal transient model for the HT-PEMFC. The model can explain the dynamic change of the oxygen concentration in the cathode gas diffusion layer and the cathode channel. This model is useful for real time simulation and multiscale fuel cell models.

Grigoriev et al. [46] developed a 2-D model of the PBI-based PEMFCs to optimize the efficiency by considering the design of the flow field channels, the current transfer ribs of the bipolar plates, and gas diffusion in the electrodes. To predict the effects of PBI loading on the PBI-based HT-PEMFC, Su et al. [47] developed a simplified two dimensional model for this PBI-based PEMFC. The model can numerically predict the cell characteristics under different conditions. A two dimensional model of the PBI-based PEMFC that considered convective and diffusive fuel transport was constructed by Sohn et al. [48]. Diffusion and convection should be enhanced for the anode gas diffusion layer, but convection needs to be suppressed in the case of a cathode gas diffusion layer. Bergmann et al. [49] investigated the performance of a phosphoric acid doped PBI membrane fuel cell based on a two dimensional and non-isothermal fuel cell model that took into account CO poisoning.

\subsection{Three dimensional models}

There are many studies that developed a three dimensional model of the HT-PEMFC to correctly predict its performance and behavior. The model describes all of the transport and polarization phenomena, and accounts for the effect of the gas channel flow rates. A three dimensional isothermal model of an HT-PEMFC based on a PBI membrane was developed by Ubong et al. [50]. The model can be used to predict the cell performance and the distribution of the fuel and local current density. Sinha et al. [51] developed a three dimensional, non-isothermal model to investigate the performance of the PEMFCs using a Gore-Select membrane at elevated temperatures under various operating conditions. Numerical studies revealed that in operation at $95^{\circ} \mathrm{C}$, oxygen transport and its depletion along the flow direction played a critical role in the cell performance even under low humidity conditions.

$\mathrm{Su}$ et al. [52] applied a three dimensional, non-isothermal model with a PTFE (polytetrafluoroethylene)/Nafion/silicate (PNS) membrane. The local characteristics in the HT-PEMFC can be reasonably predicted, which include the distribution of liquid water saturation, membrane conductivity, fuel gas depletion, temperature, current density, etc. They also claimed that the supply of the fuel gas is not sufficient to meet the requirements of the electrochemical reaction, resulting in a decrease in the cell power generation. 
A transient three dimensional, single phase and non-isothermal numerical model of a polymer electrolyte membrane (PEM) fuel cell with a high operating temperature was developed by Peng et al. [53]. This model includes a charge double layer and thermal effects on the output current. In the simulation, the current changed smoothly and there was no overshoot or undershoot with the influence of the charge double layer effect. The maximum temperature was located in the cathode catalyst layer, and both the average fuel cell temperature and temperature deviation increased with a corresponding increase in the current load.

Park and Min [54] developed a quasi-three dimensional non-isothermal dynamic model of an HT-PEMFC. Compared to the three dimensional models using CFD, a quasi-three dimensional model has an advantage in terms of a simpler geometry and can predict the distribution of the local current density, temperature, and species concentrations within minutes.

Chippar and Ju [55] focused on the modeling of an HT-PEMFC using phosphoric acid-doped polybenzimidazole membranes. A three dimensional, non-isothermal model was proposed and the key thermal aspects in term of the heat sources generated during its operation was described in order to investigate the thermal gradient along the coolant flow path. They also proposed a gas crossover model for the HT-PEMFC [56]. The dissolution of hydrogen/oxygen in the electrolyte phase and subsequent diffusion through the membrane was considered.

Kvesic et al. [57] presented a computational fluid dynamics model of the HT-PEMFC short stack to describe the flow distribution of the reacting gases and the cooling media in the stack's manifolds. They also proposed a model of the HT-PEMFC stack operated with a reformate gas [58]. CO poisoning was included in the model. The results showed that the stack model with separated manifold analysis is suitable for predicting the current density and temperature distribution for each cell and can be used to design the flow arrangement and cooling strategy.

Recently, Jiao et al. [59] developed a non-isothermal model of the HT-PEMFC that took into account the effect of CO on the fuel cell performance. They found that $\mathrm{CO}$ has a drastic effect on the HT-PEMFC at $190{ }^{\circ} \mathrm{C}$ when the CO faction in the hydrogen feed was higher than $10 \%$. They then presented a three dimensional, non-isothermal model of the HT-PEMFC with various flow channel configurations to study the combined effect of flow channel design and CO poisoning on cell performance [60]. However, the electro-oxidation of $\mathrm{CO}$ was neglected and the hydrogen adsorption rate was assumed to be constant. Oh et al. [61] applied the three dimensional, non-isothermal HT-PEMFC model developed by Chippar and Ju [55], where the effect of CO poisoning via $\mathrm{CO}$ electrooxidation was included in the model.

\section{Fuel options}

Most fuel cells use pure hydrogen or a hydrogen-rich gas as a feed. The quality of the hydrogen depends on the type of fuel cell. The LT-PEMFCs and HT-PEMFCs require a high purity hydrogen. However, the HT-PEMFC offers a higher tolerance to fuel impurities than the LT-PEMFC because CO adsorption on the electrodes at the platinum sites decreases when the temperature increases. The use of pure $\mathrm{H}_{2}$ still has some problems in terms of storage, safety and refueling. Moreover, the available infrastructures cannot be assumed. Therefore, to resolve these problems, searching for new alternative easy-to-handle fuels, such as a petroleum-based fuel, biomass and alcohol derivatives, which can be fed to the fuel processor as a raw fuel to produce $\mathrm{a} \mathrm{H}_{2}$ rich gas is a topic of interest.

Several works studied the effects of the fuel type, fuel processor and the addition of gas conditioning equipment on the feed specification and performance of the HT-PEMFCs. Araya et al. [62] studied the effects of reformate gas impurities on a $\mathrm{H}_{3} \mathrm{PO}_{4}$-doped PBI membrane-based HT-PEMFC. CO is the impurity with the most poisoning effect, while $\mathrm{CO}_{2}$ has only minor effects. Authayanun et al. [63] proposed the optimal hydrogen production conditions (reforming temperature and steam to the glycerol molar ratio) of a glycerol steam reforming process for an HT-PEMFC system without a water gas shift (WGS) reactor. To directly use a reformate gas from glycerol reforming for an HT-PEMFC, it is necessary to keep the CO content of the reformate gas under a desired range. The steam reformer should be operated at low temperature. However, a high steam to glycerol ratio is required. Performance analyses of the HT-PEMFC and LT-PEMFC fueled by pure hydrogen and reformed glycerol were conducted, and the results demonstrated that the LT-PEMFC provided a higher performance than the HT-PEMFC operated with pure hydrogen. However, the latter with a WGS reactor was better [64]. Typically, the CO concentration of the reformate gas from various reforming processes is higher than $2 \%$ (dry basis) under the optimal conditions, providing a high hydrogen yield. An amount of $\mathrm{CO} \approx 0.5 \%-2 \%$ (dry basis) was obtained from a reformate gas treated by a WGS reactor $[65,66]$.

Methanol is another fuel that can be derived from renewable sources such as biomass. It has the benefit of having an energy density 5-7 times that of hydrogen. Moreover, it is sulfur-free and is easily handled, stored and transported. Therefore, attention has been paid to the use of methanol in fuel cell applications, especially in HT-PEMFCs. There are two ways that methanol can be supplied to the fuel cell, either directly as a direct methanol fuel cell (DMFC) or indirectly where it is reformed to $\mathrm{H}_{2}$ and $\mathrm{CO}$ prior to its being fed to the fuel cell. Pan et al. [67] investigated the performance of an HT-PEMFC using a reformate gas directly from a simple methanol reformer without further CO removal. A significant performance loss was observed at a fuel cell temperature of $100{ }^{\circ} \mathrm{C}$ when the fuel was switched from pure hydrogen to the methanol reformate. However, they found that the performance loss was reduced when the temperature was increased. An HT-PEMFC fueled by reformed methanol was investigated by Andreasen et al. [68]. They revealed that the derived reformate gas quality was consistent with the HT-PEMFC feed specification and could efficiently support the HT-PEMFC.

In the DMFC system, a novel internal reforming methanol HT-PEMFC, where a methanol reforming catalyst was incorporated into the anodic compartment of fuel cell, was proposed by Avgouropoulos et al. [69]. The system demonstrated prom- 
ising electrochemical behavior and could smoothly operate for longer than $72 \mathrm{~h}$. The effect of the methanol-water vapor mixture was investigated and it was found that high concentrations of the vapor mixtures of $5 \%$ and $8 \%$ by volume in the anode can degrade the performance of $\mathrm{H}_{3} \mathrm{PO}_{4} / \mathrm{PBI}$-based fuel cell [70]. Snytnikov et al. [71] reported that a reformate gas from a methanol, DME and ethanol reforming process with $\mathrm{CuCeAl}$ and CuCe catalysts can be directly used as a fuel for the HT-PEMFC with good performance.

\section{Design of HT-PEMFC systems}

\subsection{HT-PEMFC integrated with a fuel processor}

The design of a PEMFC system depends on the fuel. The PEMFC systems for hydrogen-rich gas operation are more complicated than the pure hydrogen systems because fuel processing need to be added to the system for the production of hydrogen to supply the PEMFC. However, an HT-PEMFC integrated with a fuel processor system is less complicated than a conventional PEMFC due to: (1) no need of a hydrogen infrastructure and storage, (2) a high CO tolerance, (3) the possibility of the utilization of the excess heat of the fuel cell for use in the fuel processor. The fuel processor for HT-PEMFC systems typically requires hydrogen production and a simple purification process. Steam reforming and autothermal reforming are the most competitive fuel processing options in terms of fuel processing efficiency. This is due to the high yields of hydrogen of the steam reforming process, a good dynamic response and low external energy requirement of the autothermal reforming process [72,73]. In addition, only a WGS reactor is required for the HT-PEMFC system due to the high CO tolerance of the HT-PEMFC. An HT-PEMFC integrated with a fuel processor system is shown in Fig. 3. Due to the heat integration between the PEMFC and the reforming process, the energy required for the reforming process is partially supplied by the heat recovery from the anode and cathode off gases.

HT-PEMFCs integrated with steam and autothermal processors have been studied by many researchers [74-78]. Jaggi and Jayanti [74] have proposed a stand-alone power unit, which is an integrated auto-thermal ethanol reformer for use with HT-PEMFCs and LT-PEMFCs. The unit offered $41 \%$ and $80 \%$ overall efficiency and thermal efficiency, respectively. Gardemann et al. [75] developed a compact ethanol autothermal processor integrated with an HT-PEMFC system for small scale power generation. The system demonstrated advantages in terms of compactness and reliable start-up. The most time-consuming step is the heating of the shift reactor. Wichert et al. [76] developed a LPG fuel processor integrated with an HT-PEMFC system. They proposed that the main reactors of the system can be operated with stable performance and were easy to control during long term experiments. A fuel processor consisting of a diesel steam reformer and WGS reactor integrated with a 5-cell HT-PEFC stack was studied by Engelhardt et al. [77]. They revealed that no degradation was observed and reformer catalyst regeneration was unnecessary during the experiment which was carried out for $18 \mathrm{~h}$.

Authayanun et al. [78] investigated hydrogen production from a glycerol steam reformer for HT-PEMFCs. They revealed that the water produced from the electrochemical reactions of the HT-PEMFC can sufficiently supply the steam reformer. However, an external heat requirement was needed to maintain the steam reforming to achieve high system efficiency at high fuel utilization. They also studied an integrated HT-PEMFC system with different fuel options [79]. The necessity of a WGS reactor to eliminate $\mathrm{CO}$ in the reformate gas was analyzed. The HT-PEMFC systems fueled by methanol without the WGS reactor and methane with the WGS reactor achieved the highest system efficiency (50\%) when the heat integration between the fuel processors and the HT-PEMFCs were considered. The effects of the reformer operating conditions of the methane autothermal reformer on the efficiency of an integrated HT-PEMFC system were investigated by Park and Min [80]. An increase in the autothermal inlet temperature enhanced the efficiency of the system. However, high S/C ratio and $\mathrm{O} / \mathrm{C}$ ratios have detrimental effects on efficiency due to an increase in the heat of vaporization of water and a reduction in the concentration of hydrogen in the reformate.

High HT-PEMFC system efficiency can be achieved with an intensive heat integration within the HT-PEMFC system [81]. Hence, heat integration system studies are of the utmost importance along with the development of novel reforming catalysts, clean-up systems and PEMFC components when on-board hydrogen production is desired. The possible utilization of the excess heat of the fuel cell was addressed by Jensen et al. [82]. The heat balances were calculated for systems with methanol and methane reformers in combination with an HT-PEMFC. The use of excess heat from the HT-PEMFC for the vaporization of the reactant in the methanol and methane systems can save fuel energy by $11.1 \%$ and $9.6 \%$, respectively. In addition, the heat integration of an integrated steam reforming fuel processor with an HT-PEMFC using methane as fuel was analyzed by Pasdag et al. [83]. It was found that using HT-PEMFC heat or utilizing condensing burner technology can increase the electrical system efficiency by $5.9 \%$ and $5.5 \%$. Rabiu et al. [81] applied the technique of pinch technology to

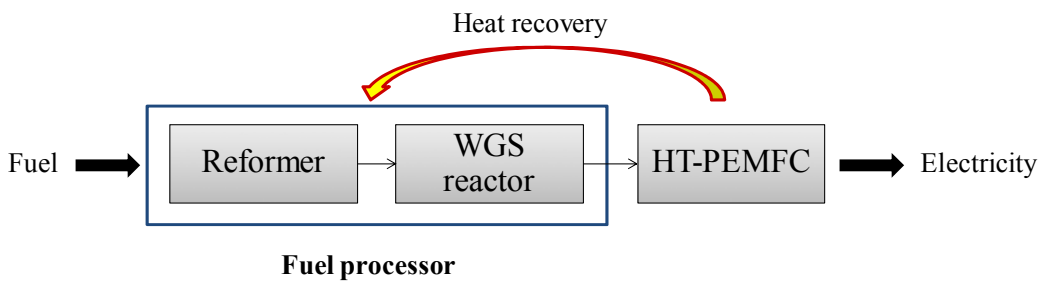

Fig. 3. HT-PEMFC integrated with a fuel processor system. 
design the heat exchanger network for maximum energy recovery of a domestic combined heat and power system consisting of a $2 \mathrm{~kW}$ HT-PEMFC integrated with a methane steam reformer. The design of the heat recovery can improve the system efficiency by $5 \%$. Samsun et al. [84] developed a $5 \mathrm{~kW}_{\mathrm{e}}$ high temperature polymer electrolyte fuel cell system operated with diesel and kerosene. System operation without external heat input was demonstrated and a system efficiency of $24 \%$ was obtained. A summary of the steam and autothermal reforming of various fuels for HT-PEMFC systems studied is presented in Table 1.

\subsection{HT-PEMFC with combined heat and power generation systems}

Combined heat and power (CHP) generation systems enable the simultaneous generation of heat and power in a single energy process. The main advantages of CHP systems are that they provide high system efficiency and the reduction of environmental pollution [88]. Due to the exothermic nature of the electrochemical reactions, the heat generated from these reactions must be removed from the fuel cell. The use of waste heat for cooling and heating is an effective option to improve system efficiency. Additionally, part-load operations can be efficiently operated with fuel cell-based micro-CHP technology [89]. Most of the research has focused on high temperature fuel cell-based CHP systems, such as solid oxide fuel cell-based CHP systems and molten carbonate fuel cell-based CHP systems because their high operation temperature yields high quality heat. However, other research has focused on small co-generation systems based on conventional PEMFCs that are operated at temperatures below $100{ }^{\circ} \mathrm{C}$ [90-92]. Low grade waste heat is recovered from the stack and exhaust gases for low temperature thermal usage, such as space heating and domestic hot water. However, the study of HT-PEMFC-based micro-CHP systems is still limited compared to other types of fuel cell-based micro-CHP systems. In the research of HT-PEMFCbased micro-CHP systems, the energy recovery from HT-PEMFCs is applied in two ways, which are heating and cooling (using an absorption chiller). The configurations of a HT-PEMFC-based micro-CHP system to produce heating and cooling are shown in Figs. 4 and 5.

An HT-PEMFC-based micro-CHP system to provide electricity and heating by hot water and space heating has been stud-

Table 1

Summary of the steam and autothermal reforming of various fuels for HT-PEMFC systems.

\begin{tabular}{lcc}
\hline Hydrogen production process & Fuel & Literature \\
\hline Autothermal reforming & Ethanol & {$[74,75]$} \\
Autothermal reforming & LPG & {$[76]$} \\
Autothermal reforming & Diesel and kerosene & {$[84]$} \\
Steam reforming & Diesel & {$[77]$} \\
Steam reforming & Glycerol & {$[78,79]$} \\
Steam reforming & Ethanol & {$[79]$} \\
Steam reforming & Methane & {$[79-83,85]$} \\
Steam reforming & Natural gas & {$[86]$} \\
Steam reforming & Methanol & {$[79,82,87]$} \\
\hline
\end{tabular}

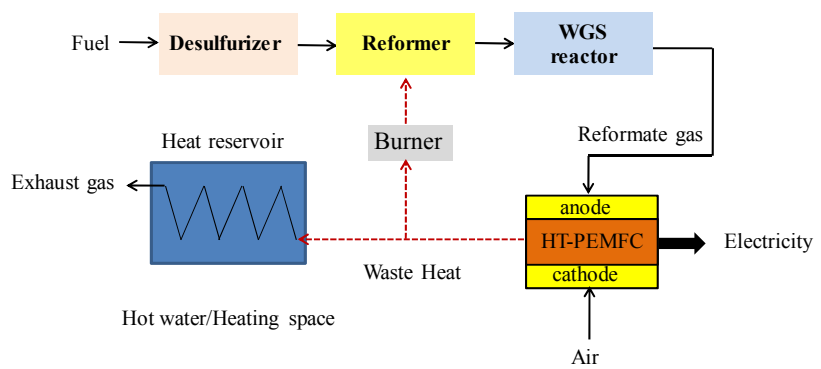

Fig. 4. Configuration of a HT-PEMFC-based micro-CHP system to produce heating.

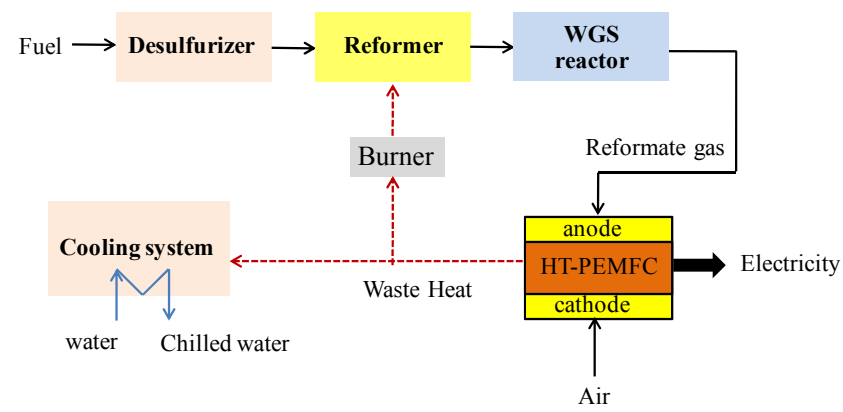

Fig. 5. Configuration of a HT-PEMFC-based micro-CHP system to produce cooling.

ied in several works [86,87,93-96]. Jannelli et al. [86] studied the integrated systems based on a natural gas steam reformer and an HT-PEMFC system. The highest cogeneration efficiency of $80 \%$ was achieved at a low stacks operating temperature since heat recovery from the cell decreases with this factor. However, the availability of high temperature heat makes the HT-PEMFC an attractive solution for the development of cogeneration/trigeneration systems. Romero-Pascual et al. [87] investigated a system for micro-CHP generation using a combustor, a methanol steam reformer and an HT-PEMFC. They revealed that $\mathrm{H}_{2}$ utilization plays a significant factor in balancing the power efficiency and produced hot water. The system CHP efficiency and hot water production increased with decreasing $\mathrm{H}_{2}$ utilization, while power efficiency was reduced.

Korsgaard et al. [93] proposed the modeling of an HT-PEMFC-based micro-CHP system. The heat from the fuel cell was collected in the heat reservoir to produce hot water for household usage. The system achieved a combined cogeneration system efficiency that was more than $30 \%$ better than the best low temperature PEM-based systems. Average electrical efficiency above $40 \%$ LHV, and higher than 90\% LHV total efficiency were obtained. An integrated HT-PEMFC system fueled by glycerol was studied and compared with a conventional LT-PEMFC system by Authayanun et al. [64]. The highest efficiencies obtained from the HT-PEMFC system were approximately $33 \%$ and $37.5 \%$ at full load and partial load conditions, respectively. Furthermore, the efficiency of the HT-PEMFC system can be increased up to $60 \%$ when the heat generated in the fuel cell was used to produce hot water for the cogeneration system (household usage).

Arsalis et al. [94] investigated a 1 kWe HT-PEMFC-based 
residential micro-CHP system for Danish single-family households. The HT-PEMFC was integrated with a fuel processor consisting of a methane steam reformer and a WGS reactor. The waste heat was applied for space heating and producing hot water. The electrical efficiencies of the partial $(25 \%)$ and full load were $45.4 \%$ and $38.8 \%$, respectively. They examined the optimal net electrical efficiency by an optimization strategy and obtained a value of net electrical efficiency (objective function) of $41.2 \%$, while the value of combined cogeneration system efficiency was $91 \%$ [95]. They also concluded that the system has to be coupled to the grid network and must incorporate an external burner system in order to continue operation at low efficiencies and to allow for the shutdown of the system during times of low electrical demand. Compared to Stirling engines and internal combustion engine-based systems, an HT-PEMFC based residential micro-CHP system possesses a significantly higher net efficiency.

The recovery of waste heat from the fuel cell can also be used to generate cooling through an absorption chiller subsystem. An absorption chiller is a refrigerant fluid cycle that utilizes waste heat to provide cooling. The two most widespread refrigerants used are water/lithium bromide ( $\mathrm{LiBr}$ ) and ammonia/water. As shown in Fig. 6, an absorption cycle of water/LiBr consists of four main components, namely a generator, absorber, condenser and evaporator. The waste heat is utilized in the generator to desorb the refrigerant from the absorbent and then the vaporized refrigerant is condensed in the condenser. The liquid refrigerant is depressurized through the expansion valve and then is piped to the evaporator. To produce useful cooling, the refrigerant absorbs heat and evaporates. Then, it is absorbed by an absorbent and becomes a solution at high pressure.

The absorption chiller is suitable for integration with an HT-PEMFC because it can use low temperature $\left(<200{ }^{\circ} \mathrm{C}\right)$ waste heat to provide cooling and thus enhance the overall system efficiency. The integration of an HT-PEMFC with an absorption chiller to produce electricity and chilled water was investigated by Arsalis [96]. The system achieved a high net electrical efficiency of $43.8 \%$ and the available cooling duty was $128.2 \mathrm{~kW}$ for a $\mathrm{LiBr} /$ water double-effect system. They concluded that the HT-PEMFC integrated with an absorption chiller system is a promising system in terms of technical feasibility compared to conventional power and cooling generators.

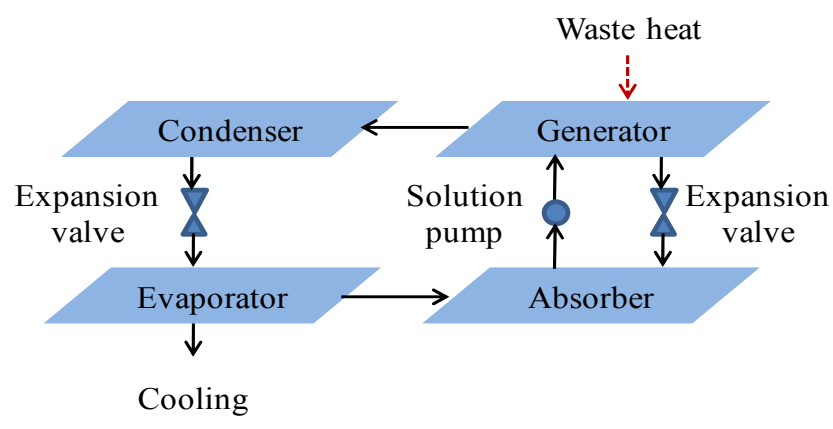

Fig. 6. Operating principle of an absorption chiller cycle.

\section{Conclusions}

A good understanding of the HT-PEMFC is required for the optimization of its performance and efficiency. The effect of different fuels, namely, pure hydrogen, reformate gas and methanol, on the operation and performance of the HT-PEMFC was discussed. Hydrogen and CO amounts affect the HT-PEMFC performance and different fuel sources for hydrogen production can cause different product gas compositions. The performance of an HT-PEMFC fueled by a reformate gas derived from different renewable sources is an interesting topic. Models of the HT-PEMFC in one, two and three dimensions and including CO poisoning have been developed. Due to the slower kinetics of the oxygen reduction in the cathode of the HT-PEMFC even at high operating temperatures, new catalysts in place of the current $\mathrm{Pt} / \mathrm{C}$ catalyst have been investigated to produce cheaper and more efficient fuel cells. The membrane used as an electrolyte for HT-PEMFCs differs from that for conventional PEMFCs, and a summary of membrane development was also given. Recovery heat from the HT-PEMFC can be applied to a main reformer to produce heating (hot water) and cooling (through an absorption chiller) to improve the overall system efficiency. The availability of high temperature heat makes the HT-PEMFC an attractive solution for the development of cogeneration/trigeneration systems.

\section{References}

[1] Song W, Yu H M, Shao Z G, Yi B L, Lin J, Liu N. Chin J Catal (宋微, 俞 红梅, 邵志刚, 衣宝廉, 林瑾, 刘娜. 催化学报), 2014, 35: 468

[2] Yan Z Y, Li B, Yang D J, Ma J X. Chin J Catal (严泽宇, 李冰, 杨代军, 马建新. 催化学报), 2013, 34: 1471

[3] Bose S, Kuila T, Nguyen T X H, Kim N H, Lau K-t, Lee J H. Prog Polym Sci, 2011, 36: 813

[4] Dupuis A C. Prog Mater Sci, 2011, 56: 289

[5] Li Q F, Jensen J O, Savinell R F, Bjerrum N J. Prog Polym Sci, 2009, 34: 449

[6] Park C H, Lee C H, Guiver M D, Lee Y M. Prog Polym Sci, 2011, 36: 1443

[7] Antonio Asensio J, Sanchez E M, Gomez-Romero P. Chem Soc Rev, 2010, 39: 2310

[8] Li Q F, He R H, Gao J A, Jensen J 0, Bjerrum N J. J Electrochem Soc, 2003, 150: A1599

[9] Zhang J L, Xie Z, Zhang J J, Tang Y H, Song C J, Navessin T, Shi Z Q, Song D T, Wang H J, Wilkinson D P, Liu Z S, Holdcroft S. J Power Sources, 2006, 160: 872

[10] Authayanun S, Mamlouk M, Arpornwichanop A. Int J Hydrogen Energ, 2012, 37: 6808

[11] Modestov A D, Tarasevich M R, Filimonov V Y, Davydova E S. Electrochim Acta, 2010, 55: 6073

[12] Linares J J, Sanches C, Paganin V A, Gonzalez E R. Int J Hydrogen Energ, 2012, 37: 7212

[13] Oettel C, Rihko-Struckmann L, Sundmacher K. Int J Hydrogen Energ, 2012, 37: 11759

[14] Nepel T C M, Lopes P P, Paganin V A, Ticianelli E A. Electrochim Acta, 2013, 88: 217

[15] Gasteiger H A, Markovic N M, Ross P N Jr. J Phys Chem, 1995, 99 : 16757

[16] Davies J C, Hayden B E, Pegg D J. Electrochim Acta, 1998, 44: 1181 


\section{Graphical Abstract}

Chin. J. Catal., 2015, 36: 473-483 doi: 10.1016/S1872-2067(14)60272-2

\section{A review of the development of high temperature proton exchange membrane fuel cells}

Suthida Authayanun, Karittha Im-orb, Amornchai Arpornwichanop* Srinakharinwirot University, Thailand;

Chulalongkorn University, Thailand

This work presents a review of the development of HT-PEMFCs. The principal operation and aspects of HT-PEMFC research with respect to electrochemistry, membrane, modeling, fuel options and system design are presented.

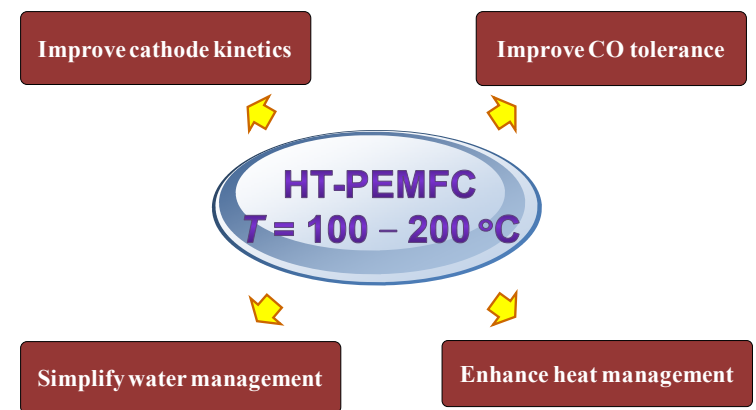

[17] Zhang S S, Yuan X Z, Hin J N C, Wang H J, Friedrich K A, Schulze M. J Power Sources, 2009, 194: 588

[18] Arico A S, Stassi A, Modica E, Ornelas R, Gatto I, Passalacqua E, Antonucci V.J Power Sources, 2008, 178: 525

[19] Borup R L, Davey J R, Garzon F H, Wood D L, Inbody M A. J Power Sources, 2006, 163: 76

[20] Colon-Mercado H R, Popov B N.J Power Sources, 2006, 155: 253

[21] Nörskov J K, Rossmeisl J, Logadottir A, Lindqvist L, Kitchin J R, Bligaard T, Jónsson H.J Phys Chem B, 2004, 108: 17886

[22] Gasteiger H A, Kocha S S, Sompalli B, Wagner F T. Appl Catal B, 2005, 56: 9

[23] Chandan A, Hattenberger M, El-kharouf A, Du S F, Dhir A, Self V, Pollet B G, Ingram A, Bujalski W. J Power Sources, 2013, 231: 264

[24] Schenk A, Grimmer C, Perchthaler M, Weinberger S, Pichler B, Heinzl C, Scheu C, Mautner F A, Bitschnau B, Hacker V. J Power Sources, 2014, 266: 313

[25] Stamenkovic V R, Mun B S, Arenz M, Mayrhofer K J J, Lucas C A, Wang G F, Ross P N, Markovic N M. Nat Mater, 2007, 6: 241

[26] Stamenkovic V R, Fowler B, Mun B S, Wang G F, Ross P N, Lucas C A, Marković N M. Science, 2007, 315: 493

[27] Toda T, Igarashi H, Uchida H, Watanabe M. J Electrochem Soc, 1999, 146: 3750

[28] Jung G B, Tseng C C, Yeh C C, Lin C Y. Int J Hydrogen Energ, 2012, 37: 13645

[29] Su H N, Pasupathi S, Bladergroen B, Linkov V, Pollet B G. Int J Hy drogen Energ, 2013, 38: 11370

[30] Lee K S, Yoo S J, Ahn D, Kim S K, Hwang S J, Sung Y E, Kim H J, Cho E A, Henkensmeier D, Lim T H, Jang J H. Electrochim Acta, 2011, 56: 8802

[31] Mamlouk M, Scott K. Int J Hydrogen Energ, 2010, 35: 784

[32] Gottesfeld S, Raistrick I D, Srinivasan S. J Electrochem Soc, 1987, 134: 1455

[33] Floriano J B, Ticianelli E A, Gonzalez E R. J Electroanal Chem, 1994, 367: 157

[34] Strmcnik D, Escudero-Escribano M, Kodama K, Stamenkovic V R Cuesta A, Marković N M. Nature Chem, 2010, 2: 880

[35] Mamlouk M, Scott K. J Power Sources, 2011, 196: 1084

[36] Park H Y, Yoo S J, Kim S J, Lee S Y, Ham H C, Sung Y E, Kim S K, Hwang S J, Kim H J, Cho E A, Henkensmeier D, Nam S W, Lim T H, Jang J H. Electrochem Commun, 2013, 27: 46

[37] Cheddie D, Munroe N. Energ Convers Manage, 2006, 47: 1490

[38] Scott K, Pilditch S, Mamlouk M. J Appl Electrochem, 2007, 37: 1245

[39] Mamlouk M, Sousa T, Scott K. Int J Electrochem, 2011, 2011: 1
[40] Kim M, Kang T, Kim J, Sohn Y J. Solid State Ionics, 2014, 262: 319

[41] Kim J, Kim M, Kang T, Sohn Y J, Song T, Choi K H. Energy, 2014, 66: 41

[42] Sousa T, Mamlouk M, Scott K. Chem Eng Sci, 2010, 65: 2513

[43] Sousa T, Mamlouk M, Scott K. Int J Hydrogen Energ, 2010, 35: 12065

[44] Shamardina 0, Chertovich A, Kulikovsky A A, Khokhlov A R. Int J Hydrogen Energ, 2010, 35: 9954

[45] Shamardina 0, Kondratenko M S, Chertovich A V, Kulikovsky A A. Int J Hydrogen Energ, 2014, 39: 2224

[46] Grigoriev S A, Kalinnikov A A, Kuleshov N V, Millet P. Int J Hydrogen Energ, 2013, 38: 8557

[47] Su A, Ferng Y M, Hou J, Yu T L. Int J Hydrogen Energ, 2012, 37: 7710

[48] Sohn Y J, Kim M, Yang T H, Kim K. Int J Hydrogen Energ, 2011, 36: 15273q.

[49] Bergmann A, Gerteisen D, Kurz T. Fuel Cells, 2010, 10: 278

[50] Ubong E U, Shi Z, Wang X.J Electrochem Soc, 2009, 156: B1276

[51] Sinha P K, Wang C Y, Beuscher U. J Electrochem Soc, 2007, 154: B106

[52] Su A, Ferng Y M, Shih J C. Appl Therm Eng, 2009, 29: 3409

[53] Peng J, Shin J Y, Song T W.J Power Sources, 2008, 179: 220

[54] Park J, Min K.J Power Sources, 2012, 216: 152

[55] Chippar P, Ju H. Solid State Ionics, 2012, 225: 30

[56] Chippar P, Ju H. Int J Hydrogen Energ, 2013, 38: 7704

[57] Kvesic M, Reimer U, Froning D, Lüke L, Lehnert W, Stolten D. Int J Hydrogen Energ, 2012, 37: 2430

[58] Kvesic M, Reimer U, Froning D, Lüke L, Lehnert W, Stolten D. Int J Hydrogen Energ, 2012, 37: 12438

[59] Jiao K, Alaefour I E, Li X G. Fuel, 2011, 90: 568

[60] Jiao K, Zhou Y B, Du Q, Yin Y, Yu S H, Li X G. Appl Energ, 2013, 104: 21

[61] Oh K, Chippar P, Ju H. Int J Hydrogen Energ, 2014, 39: 2785

[62] Araya S S, Andreasen S J, Kær S K. Energies, 2012, 5: 4251

[63] Authayanun S, Arpornwichanop A, Patcharavorachot Y, Wiyaratn W, Assabumrungrat S. Int J Hydrogen Energ, 2011, 36: 267

[64] Authayanun S, Mamlouk M, Scott K, Arpornwichanop A. Appl Energ, 2013, 109: 192

[65] Liu Q H, Liu Z L, Liao LW, Dong X F. J Nat Gas Chem, 2010, 19: 497

[66] Maciel C G, Profeti L P R, Assaf E M, Assaf J M. J Power Sources, 2011, 196: 747

[67] Pan C, He R H, Li Q F, Jensen J O, Bjerrum N J, Hjulmand H A, Jensen A B. J Power Sources, 2005, 145: 392 
[68] Andreasen S J, Kær S K, Sahlin S. Int J Hydrogen Energ, 2013, 38: 1676

[69] Avgouropoulos G, Papavasiliou J, Daletou M K, Kallitsis J K, Ioannides T, Neophytides S. Appl Catal B, 2009, 90: 628

[70] Araya S S, Andreasen S J, Nielsen H V, Kær S K. Int J Hydrogen Energ, 2012, 37: 18231

[71] Snytnikov P V, Badmaev S D, Volkova G G, Potemkin D I, Zyryanova M M, Belyaev V D, Sobyanin V A. Int J Hydrogen Energ, 2012, 37: 16388

[72] Sopena D, Melgar A, Briceno Y, Navarro R M, Alvarez-Galvan M C, Rosa F. Int J Hydrogen Energ, 2007, 32: 1429

[73] Hubert C E, Achard P, Metkemeijer R. J Power Sources, 2006, 156: 64

[74] Jaggi V, Jayanti S. Appl Energ, 2013, 110: 295

[75] Gardemann U, Steffen M, Heinzel A. Int J Hydrogen Energ, 2014 39: 18135

[76] Wichert M, Men Y, O'Connell M, Tiemann D, Zapf R, Kolb G, Butschek S, Frank R, Schiegl A. Int J Hydrogen Energ, 2011, 36: 3496

[77] Engelhardt P, Maximini M, Beckmann F, Brenner M, Moritz O. Int J Hydrogen Energ, 2014, 39: 18146

[78] Authayanun S, Wiyaratn W, Assabumrungrat S, Arpornwichanop A. Fuel, 2013, 105: 345

[79] Authayanun S, Saebea D, Patcharavorachot Y, Arpornwichanop A. Energy, 2014, 68: 989

[80] Park J, Min K. Int J Hydrogen Energ, 2014, 39: 10683

[81] Rabiu A M, Dlangamandla N, Ulleberg Ö. APCBEE Procedia, 2012,
3: 17

[82] Jensen J O, Li Q F, Pan C, Vestbö A P, Mortensen K, Petersen H N, Sörensen C L, Clausen T N, Schramm J, Bjerrum N J. Int J Hydrogen Energ, 2007, 32: 1567

[83] Pasdag 0, Kvasnicka A, Steffen M, Heinzel A. Energy Procedia, 2012, 28: 57

[84] Samsun R C, Pasel J, JanBen H, Lehnert W, Peters R, Stolten D. Appl Energ, 2014, 114: 238

[85] Arsalis A, Nielsen M P, Kær S K. Int J Hydrogen Energ, 2011, 36: 5010

[86] Jannelli E, Minutillo M, Perna A. Appl Energ, 2013, 108: 82

[87] Romero-Pascual E, Soler J. Int J Hydrogen Energ, 2014, 39: 4053

[88] Arsalis A, Nielsen M P, Kær S K. Int J Hydrogen Energ, 2011, 36: 5010

[89] Giacoppo G, Barbera O, Carbone A, Gatto I, Sacca A, Pedicini R, Passalacqua E. Int J Hydrogen Energ, 2013, 38: 11619

[90] Barelli L, Bidini G, Gallorini F, Ottaviano A. Appl Energ, 2011, 88: 4334

[91] Oh S D, Kim K Y, Oh S B, Kwak H Y. Appl Energ, 2012, 95: 93

[92] Briguglio N, Ferraro M, Brunaccini G, Antonucci V. Int J Hydrogen Energ, 2011, 36: 8023

[93] Korsgaard A R, Nielsen M P, Kær S K. Int J Hydrogen Energ, 2008, 33: 1909

[94] Arsalis A, Nielsen M P, Kær S K. Energy, 2011, 36: 993

[95] Arsalis A, Nielsen M P, Kær S K. Int J Hydrogen Energ, 2012, 37: 2470

[96] Arsalis A. Int J Hydrogen Energ, 2012, 37: 13484 